\title{
Anti-proliferative Effects of a Coumarin Benjaminin on Four Human Cancer Cell Lines
}

\author{
Siau Hui Mah" ${ }^{*}$, Soek Sin Teh², Ahmad Azri Fitri Ismail ${ }^{3}$, Gwendoline Cheng Lian Ee ${ }^{3}$ \\ ${ }^{1}$ School of Biosciences, Taylor's University, Lakeside Campus, 47500 Subang Jaya, Selangor, Malaysia \\ ${ }^{2}$ Engineering and Processing Division, Energy and Environment Unit, Malaysian Palm Oil Board, Kajang, Malaysian Palm Oil \\ Board, 43000 Kajang, Selangor, Malaysia \\ ${ }^{3}$ Department of Chemistry, Faculty of Science, Universiti Putra Malaysia, 43400 UPM Serdang, Selangor, Malaysia
}

\begin{abstract}
Cancer is a major health issue around the globe. Chemotherapy and radiation therapy are no longer the standard treatments for patients as these remedies lead to many adverse effects. Thus, the development of alternative effective drugs from lead compounds, especially natural products is necessary. This study aimed to isolate cytotoxic phytochemical constituents from a plant Calophyllum inophyllum, which has been used as traditional medicine since ancient time. The root of $C$. inophyllum was extracted and subjected for phytochemical constituent isolation. A coumarin, benjaminin (1) was isolated successfully from the chloroform extract and its structural elucidation was performed by spectroscopy analyses of MS, IR and NMR. The anti-proliferative effect of $\mathbf{1}$ on four cancer cell lines, leukemia (K562), stomach (SNU-1), liver (Hep-G2) and lung (NCI-H23) cancers were evaluated by using colorimetric MTT assay. Benjaminin (1) exhibited cytotoxic effects towards all cancer cells and showed the strongest inhibition towards SNU-1 cell proliferation with an $\mathrm{IC}_{50}$ value of $70.42 \mu \mathrm{M}$. The outcome of this study revealed that $\mathbf{1}$ is a potential cytotoxic lead compound that could be further developed into anti-cancer drug. Thus, the study on the structure-activity relationship of $\mathbf{1}$ is highly recommended in due course to improve its anti-proliferative effects on cancer cells.
\end{abstract}

Keywords: Calophyllum inophyllum, cytotoxic, isolation, MTT assay

*corresponding author

Email:SiauHui.Mah@taylors.edu.my

\section{INTRODUCTION}

Cancer is a growing health problem worldwide and characterized by uncontrollably cell growth. It is a result of mutations that inhibit oncogene and tumor suppressor gene function, which lead to uncontrollable cell growth in our body. The cancer cells do not experience programmatic death, apoptosis, resulting in a mass of abnormal cells. Standard treatments of cancer are surgery, chemotherapy, radiation, hormonal therapy, immune therapy and gene therapy. The treatment of cancer depends on the types and stages of cancer, as well as the physical status of patients. As such, the patients often receive a combination of therapies. The search for novel selective anti-cancer agents has become a priority in pharmaceutical industries. Thus, the discovery of lead compounds for anti-cancer drugs is in urgent need. Natural products are a reliable source of pharmacologically active phytochemical constituents that are potential to be the lead compounds. It has led to our study on the isolation of bioactive constituent from the natural resources, particularly Calophyllum inophyllum.
Calophyllum species have been used as folk medicine for rheumatism, haemorrhoids and ulcers. Previous studies revealed that it has potential inflammatory (Tsai et al., 2012), antimicrobial (Alkhamaiseh et al., 2012; Khan et al, 2002), anti-Helicobacter pylori (Souza et al., 2009) and cytotoxic (Alkhamaiseh et al., 2011; Mah et al., 2013) properties. These properties are deduced to be contributed by the bioactive secondary metabolites present in their plant extracts, especially coumarins (Ee et al., 2011; McKee et al., 1996). Coumarins isolated from Calophyllum species are well-known for numerous pharmacological effects such as anti-HIV (Spino et al., 1998), anti-bacterial (Verotta et al., 2004) and cytotoxicity (Guilet et al., 2001a; Win et al., 2008). In this study, we reported for the first time the isolation of a coumarin, Benjaminin (1) from the roots of $C$. inophyllum. The chemical structure of 1 was determined by the analyses of spectroscopic data, including mass spectrometry (MS), infrared (IR) and nuclear magnetic resonance (NMR). The coumarin was further evaluated for its anti-proliferative effects against four cancer cells, which are K562 (chronic myelogenous leukemia), SNU-1 (gastric carcinoma), Hep-G2 (hepatocellular carcinoma) and NCI-H23 (adenocarcinoma) cell lines 
Table 1. The ${ }^{1} \mathrm{H}$ - and ${ }^{13} \mathrm{C}-\mathrm{NMR}$ data for Benjaminin (1)

\begin{tabular}{|c|c|c|}
\hline \multirow{2}{*}{ Carbon Number } & \multicolumn{2}{|c|}{ Chemical Shift, $\delta(\mathrm{ppm})$} \\
\hline & ${ }^{1} \mathrm{H}-\mathrm{NMR}$ & ${ }^{13} \mathrm{C}-\mathrm{NMR}$ \\
\hline 1 & - & - \\
\hline 2 & - & 179.3 \\
\hline 3 & $2.74(2 \mathrm{H}, d)$ & 39.2 \\
\hline 4 & $3.51(1 \mathrm{H}, m)$ & 32.7 \\
\hline $4 \mathrm{a}$ & & 115.2 \\
\hline 5 & - & 165.0 \\
\hline 6 & - & 115.3 \\
\hline 7 & - & 160.2 \\
\hline 8 & - & 109.1 \\
\hline $8 \mathrm{a}$ & & 158.6 \\
\hline $1^{\prime}$ & $1.70(2 \mathrm{H}, m)$ & 33.9 \\
\hline $2^{\prime}$ & $1.11(2 \mathrm{H}, m)$ & 27.8 \\
\hline $3^{\prime}$ & $1.24(2 \mathrm{H}, m)$ & 32.0 \\
\hline $4^{\prime}$ & $1.22(2 \mathrm{H}, m)$ & 22.6 \\
\hline $5^{\prime}$ & $0.82(3 \mathrm{H}, t)$ & 14.2 \\
\hline $1^{\prime \prime}$ & $3.25(2 \mathrm{H}, m)$ & 22.7 \\
\hline $2^{\prime \prime}$ & $5.19(1 \mathrm{H}, t)$ & 122.9 \\
\hline $3 "$ & - & 131.8 \\
\hline $4 "$ & $1.67(3 \mathrm{H}, s)$ & 25.8 \\
\hline $5^{\prime \prime}$ & $1.74(3 \mathrm{H}, s)$ & 18.0 \\
\hline $1^{\prime \prime \prime}$ & - & 200.4 \\
\hline $2^{\prime \prime \prime}$ & $2.53(1 \mathrm{H}, m)$ & 46.2 \\
\hline $3^{\prime \prime \prime}$ & $4.13(1 \mathrm{H}, m)$ & 78.8 \\
\hline $4^{\prime \prime \prime}$ & $\begin{array}{c}1.49(3 \mathrm{H}, d, J=6.87 \\
\mathrm{Hz})\end{array}$ & 19.7 \\
\hline $5^{\prime \prime \prime}$ & $\begin{array}{c}1.19(3 \mathrm{H}, d, J=6.87 \\
\mathrm{Hz})\end{array}$ & 10.3 \\
\hline 7-OH & $12.28(1 \mathrm{H}, s)$ & - \\
\hline $5-\mathrm{OCH}_{3}$ & $3.72(3 \mathrm{H}, s)$ & 62.9 \\
\hline
\end{tabular}

by using MTT assay. This study also represents the first scientific report of the anti-proliferative effect of $\mathbf{1}$ on cancer cells.

\section{METHODS}

\section{General}

The infrared spectrum was obtained from FT-IR spectrometer (Perkin-Elmer 100 Series) by using the universal attenuated total reflection (UATR) technique. The mass spectrum was recorded by GC-MS spectrophotometer (Shimadzu GC-MS model QP2010
Plus) using electron ionization (EI) method. The 1Dand 2D-NMR spectra were collected by using NMR spectrophotometer (JEOL FT-NMR $400 \mathrm{MHz}$ ). The melting point was recorded by using a melting point device (Electrothermal IA9100).

\section{Plant Material}

The roots of $C$. inophyllum was collected in 2012 from Universiti Putra Malaysia, Serdang, Malaysia. The specimen of the plant was identified by Associate Professor Dr. Rusea Go, a botanist from the Department of Biology, Universiti Putra Malaysia and was kept in 
the Herbarium, Department of Biology, UPM with a voucher specimen number of RG5016.

\section{Extraction and Isolation}

The roots of $C$. inophyllum ( $1 \mathrm{~kg}$ ) was air-dried and ground for the extraction process by using maceration method where the solvents were used to soak the plant materials. The powdery plant materials were extracted sequentially by using hexane and chloroform. The solvents were filtered and replaced with fresh hexane after being macerated for three days. The extraction process was repeated for three times. The filtered extracts were dried under vacuum by using rotary evaporator to obtain the dried crude extracts.

The chloroform extract was subjected to purification by using column chromatography with a series of solvent systems. Approximately $20 \mathrm{~g}$ of the crude extract was loaded into an opened glass column chromatography with pre-packed silica gel and eluted with hexane, chloroform and methanol in a stepwise gradient system. A total of 43 fractions were obtained and fractions pooling were performed. Fractions 5-11 were pooled and further purified using the same chromatographic technique to give another 13 fractions. Subsequently, fractions 4-8 gave a yellowish oily gum and was further purified to afford yellowish crystals $(22 \mathrm{mg})$. The structural elucidation of this compound was achieved using NMR, GC-MS and FT-IR spectroscopic methods.

\section{Spectral Data}

Benjaminin (1). Yellow crystals. m.p. 245-246 ${ }^{\circ} \mathrm{C}$. EIMS: $m / z 432$ with molecular formula $\mathrm{C}_{25} \mathrm{H}_{36} \mathrm{O}_{6} \cdot{ }^{1} \mathrm{H}-\mathrm{NMR}$ $\left(\mathrm{CDCl}_{3}, 400 \mathrm{MHz}\right)$ and ${ }^{13} \mathrm{C}-\mathrm{NMR}\left(\mathrm{CDCl}_{3}, 100 \mathrm{MHz}\right)$ : Table 1 .

\section{MTT Assay}

The antiproliferative assays were examined by colorimetric MTT assay as described by Mosmann et al (1983). In this study, four cancer cell lines, K562, SNU1, Hep-G2 and NCI-H23 cells from ATCC were used. Cisplatin was used as a standard drug in this assay. All the cancer cells were cultured in the RPMI medium supplemented with $10 \%$ fetal bovine serum. The concentration of the K562 cells used was $2.0 \times 10^{5}$ cells/ $\mathrm{mL}$ while SNU-1, Hep-G2 and NCI-H23 cells were $1.0 \mathrm{x}$ $10^{5}$ cells $/ \mathrm{mL}$. Serial dilution of 1 was performed to obtain five different concentrations. For suspension cells (K562 and SNU-1 cells), the concentrations prepared were $200.00,100.00,50.00,25.00,12.50,6.25 \mu \mathrm{g} / \mathrm{mL}$. On the other hand, 100.00, 50.00, 25.00, 12.50, 6.25 and 3.13 $\mu \mathrm{g} / \mathrm{mL}$ were the concentrations prepared for anchoragedependent cells (Hep-G2 and NCI-H23 cells). The assay was conducted in triplicate for both the compound and standard drug.
Briefly, $100 \mu \mathrm{L}$ of the cancer cells were seeded into the 96 well plate and followed by $100 \mu \mathrm{L}$ of compound. For the suspension cells, the compound was added immediately after the addition of cells while the compound was added after 24 hours of cell seeding for anchorage-dependent cells. The plate was then incubated for 72 hours in an incubator with $5 \% \mathrm{CO}_{2}$ and temperature of $37{ }^{\circ} \mathrm{C}$. The addition of $20 \mu \mathrm{L}$ of MTT solution into each well was carried out and the plate was incubated for another 3 hours. Afterwards, $150 \mu \mathrm{L}$ of supernatant of each well were discarded and replaced with the same amount of DMSO to dissolve the purple formazan. The absorbance of each well was read at $550 \mathrm{~nm}$ after to obtain the percentage of cell viability. The $\mathrm{IC}_{50}$ values of the compound for each cancer cell were obtained from the graph of percentage of cell viability vs. concentration.

\section{Statistical Analysis}

All the data were expressed as mean \pm standard deviation (SD). The statistical analysis was conducted by using Graph Pad Prism with $t$-test or one-way ANOVA. The level of significance used was $p<0.05$.

\section{RESULTS AND DISCUSSION}

Benjaminin (1) was isolated successfully from the chloroform extract of the root of $C$. inophyllum. It is a coumarin with the chemical structure presented in Figure 1. The compound appears as yellow crystals with melting point of $245-246{ }^{\circ} \mathrm{C}$. The mass spectrum of the compound demonstrated a molecular ion peak $[\mathrm{M}]^{+}$at $\mathrm{m} / \mathrm{z} 432$ which is consistent with the molecular formula of $\mathrm{C}_{25} \mathrm{H}_{36} \mathrm{O}_{6}$. The FT-IR spectrum exhibited absorptions of hydroxyl group (OH) at $3296 \mathrm{~cm}^{-1}, s p^{2}$ and $s p^{3} \mathrm{C}-\mathrm{H}$ stretch at 2970 and $2925 \mathrm{~cm}^{-1}$, conjugated carbonyl $(\mathrm{C}=\mathrm{O})$ at $1705 \mathrm{~cm}^{-1}$ and aromatic group $(\mathrm{C}=\mathrm{C}$ aromatic $)$ at 1626 and $1470 \mathrm{~cm}^{-1}$.<smiles>CCCCCC1CC(=O)Oc2c(C(=O)C(C)C(C)O)c(O)c([CH]C=C(C)C)c(OC)c21</smiles>

Figure 1. Chemical structure of Benjaminin (1) 
The ${ }^{1} \mathrm{H}$ - and ${ }^{13} \mathrm{C}$-NMR data of $\mathbf{1}$ were presented in Table 1. The spectrum of ${ }^{1} \mathrm{H}$ NMR implied the presence of a chelated hydroxyl group with a chemical shift found at $\delta$ 12.28, which correlates to $\delta 109.1$ (C-8) and 115.3 $(\mathrm{C}-6)$ and $\delta 160.2(\mathrm{C}-7)$ through ${ }^{2} J$ and ${ }^{3} J$ correlations in $\mathrm{HMBC}$ spectrum, indicating its attachment to C-7 of the coumarin. Moreover, the chemical shifts of $\delta$ $3.25\left(\mathrm{H}-1^{\prime \prime}\right), 5.19\left(\mathrm{H}-2^{\prime \prime}\right), 1.67$ (H-4") and $1.74\left(\mathrm{H}-5^{\prime \prime}\right)$ demonstrated the presence of a prenyl moiety. The proton signal at $\delta 3.25$ (H-1") shows coupling with $\delta 22.7$ (C1 ") in HMQC spectrum and long-term correlations with $\delta 115.3$ (C-6), $\delta 160.2$ (C-7) and $\delta 165.0$ (C-5) in HMBC spectrum. It confirms that the prenyl moiety is attached to the coumarin at position C-6. Another substituent group, $n$-pentyl that is attached at C-4 were observed by a series of upfield chemical shifts, including $\delta 1.70(\mathrm{H}-$ $\left.1^{\prime}\right), 1.11\left(\mathrm{H}-2^{\prime}\right), 1.24\left(\mathrm{H}-3^{\prime}\right), 1.22\left(\mathrm{H}-4^{\prime}\right)$ and $0.82\left(\mathrm{H}-5^{\prime}\right)$, in addition to $\mathrm{HMBC}$ correlations of $\mathrm{H}-4$ and $\mathrm{H}-3$ with $\delta 33.9$ (C-1') and $\delta 27.8$ (C-2'), respectively. Besides that, the chemical shift of $\delta 3.72$ belongs to the methoxyl group at C-5. Consequently, the side chain of 3-hydroxy2-methylbutanoyl is attached to the coumarin at position $\mathrm{C}-8$. For the ${ }^{13} \mathrm{C}$ NMR spectrum, the number of peaks obtained are in accordance with the total number of carbons present in the structure of $\mathbf{1}$. Both the ${ }^{1} \mathrm{H}$ and ${ }^{13} \mathrm{C}$ NMR spectra are consistent with the previously reported data (Sahimi et al., 2015). Thus, Benjaminin (1) is confirmed to be isolated for the first time from the root of C. inophyllum.

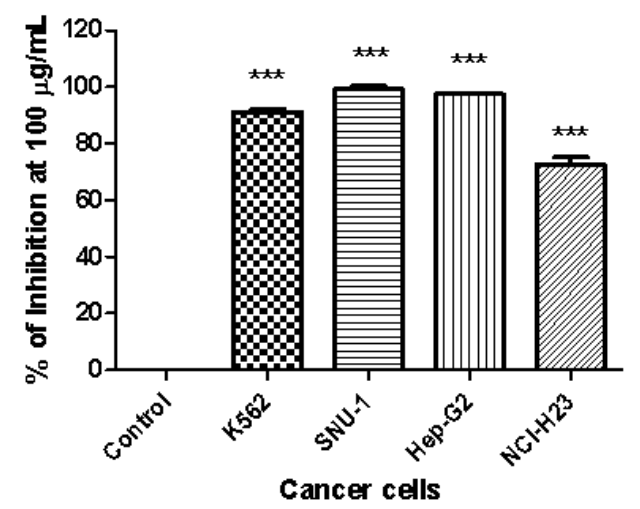

Figure 2. Anti-proliferative effects of Benjaminin (1) at the concentration of $100 \mu \mathrm{g} / \mathrm{mL}$ on K562, SNU-1, Hep-G2 and NCI-H23 cells. The values are expressed as mean \pm SD from three separate experiments. *** p $<0.05$ by t-tests

Benjaminin (1) was evaluated for its anti-proliferative activities against four cancer cell lines by MTT method and reported for the first time in this study. The cell lines used were human erythroleukemia (K562), human gastric cancer (SNU-1), human liver hepatocellular carcinoma (Hep-G2) and human lung cancer (NCI-H23) cell. The anti-proliferative effects of these cancer cells proliferative by 1 at the concentration of $100 \mu \mathrm{g} / \mathrm{mL}$ are presented in Figure 2. This compound showed potential inhibitory effects against all the cancer cell lines with the strongest effect observed for SNU-1 cell line (99.36 \pm $0.93 \%$ ). It is followed by Hep-G2 and K562 cell lines with $97.42 \pm 0.50 \%$ and $91.19 \pm 0.82 \%$, respectively. Lastly, the anti-proliferative effect against NCI-H23 cell line is the weakest with an inhibition percentage of 72.72 $\pm 2.42 \%$.

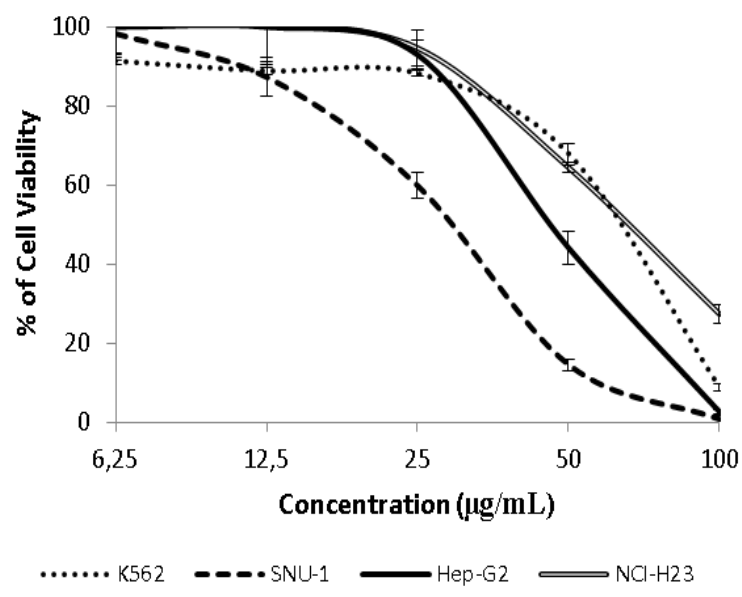

Figure 3. Cytotoxicity of Benjaminin (1) towards K562, SNU-1, Hep-G2 and NCI-H23 cells at different concentrations. Each data point represents the mean \pm SD of three independent experiments.

The cytotoxic effects of $\mathbf{1}$ towards cancer cells are shown in a concentration-dependent manner (See Figure 3 ). Thus, the $\mathrm{IC}_{50}$ values of cytotoxicity of $\mathbf{1}$ against all the human cancer cell lines were determined from the graph of percentage of cell proliferative inhibition against the concentration and summarized in Table 2 . Cisplatin, which was used as a standard drug showed cytotoxic activity with the $\mathrm{IC}_{50}$ values ranging from 4 to $10 \mu \mathrm{M}$. The lowest $\mathrm{IC}_{50}$ value of cytotoxicity for $\mathbf{1}$ was observed for the stomach cancer cells, SNU-1 which is $70.42 \pm 3.56 \mu \mathrm{M}$, indicating the strongest inhibition towards SNU-1 cell proliferation. The $\mathrm{IC}_{50}$ values of 1 obtained for the liver cancer cells, Hep-G2 cells is $109.65 \pm 2.36 \mu \mathrm{M}$, which is higher than SNU-1 cells. The anti-proliferative activities of K562 and NCI-H23 cell lines were found to be weaker with the $\mathrm{IC}_{50}$ values of $150.72 \pm 3.21$ and $160.42 \pm 6.46 \mu \mathrm{M}$, respectively. These data suggest that 1 could be a potential cytotoxic lead compound to be further developed as anticancer drug. The potential cytotoxic properties of coumarins present in Calophyllum species were supported by previous studies.

Six coumarin derivatives were previously isolated successfully from $C$. dispar by Guilet et al. (2001a) and these coumarins were claimed to have cytotoxicity against KB cells. The coumarins, Isodispar B, disparpropylinol B and disparinol B showed significant 
Table 2. The $\mathrm{IC}_{50}$ values of cytotoxicity of Benjaminin (1) towards K562, SNU-1, Hep-G2 and NCI-H23 cells

\begin{tabular}{lll}
\hline \multirow{2}{*}{ Cancer Cell Line } & \multicolumn{2}{c}{$\mathbf{I C}_{\mathbf{5 0}}(\boldsymbol{\mu M})$} \\
\cline { 2 - 3 } & \multicolumn{1}{c}{ Benjaminin (1) } & Cisplatin \\
\hline K562 & $150.72 \pm 3.21$ & $4.08 \pm 0.09$ \\
SNU-1 & $70.42 \pm 3.56$ & $9.64 \pm 0.59$ \\
Hep-G2 & $109.65 \pm 2.36$ & $8.67 \pm 1.22$ \\
NCI-H23 & $160.42 \pm 6.46$ & $5.32 \pm 1.69$ \\
\hline
\end{tabular}

The values are expressed as mean $\pm \mathrm{SD}$ in triplicate.

effects by inhibiting $50 \%$ of the cellular growth at the concentration ranging from 4 to $8 \mu \mathrm{g} / \mathrm{mL}$. In the same year, the authors reported the isolation of another eleven furanocoumarins from the same plant together with their anti-proliferative effects against the same cell line, KB cells. Mammea A/BA cyclo F, mammea A/AA cyclo F, mammea $\mathrm{A} / \mathrm{AB}$ cyclo $\mathrm{F}$ and mammea $\mathrm{A} / \mathrm{AC}$ cyclo $\mathrm{F}$ are the coumarins that exhibited significant antiproliferative effects against $\mathrm{KB}$ cells with the $\mathrm{ED}_{50}$ values of less than $10 \mu \mathrm{g} / \mathrm{mL}$ (Guilet et al, 2001b). Furthermore, ReyesChilpa et al. (2004) reported that these mammea-typed coumarins, which were isolated from $C$. brasiliense, were cytotoxic against three human tumor cell lines, K562, U251, and PC3 cells. Mammea A/BA possessed the strongest activities among the coumarins with the $\mathrm{IC}_{50}$ values of less than $0.59 \mu \mathrm{M}$ for all cell lines (ReyesChilpa et al., 2004).

In terms of structure-activity relationship, the cytotoxic effect of $\mathbf{1}$ is deduced to be contributed by the prenyl moiety attached to position C- 6 of the coumarin. This statement is supported by a previous study that examined the inhibitory effects of EBV-EA activation in Raji cells on ten 4-phenylcoumarins isolated from C. inophyllum. The authors suggested that Calocoumarin-A, which has a prenyl moiety at C-6, exhibited the most potent inhibitory activity (Itoigawa et al., 2001). This is further confirmed by another study on thirty-two 7-methoxycoumarins isolated from other plants, Murraya and Citrus species. This investigation study indicated that the coumarin with a prenyl moiety at C-6 showed significant inhibitory effects, as seen in 6,8-di(30-methyl-20-butenyl)-7methoxycoumarin, which is the most potent compound among the coumarins tested (Ito et al., 1999). As a summary, benjaminin (1) is a valuable potential cytotoxic lead compound that can be developed as an anti-cancer drug. Therefore, a future study on the design and synthesis of more potent analogues, particularly for the anti-proliferative effects on stomach cancer cell line, SNU-1 is worthwhile.

\section{CONCLUSIONS}

A coumarin, benjaminin (1) was successfully isolated from the root of $C$. inophyllum. This compound has anti-proliferative effects on four cancer cell lines, K562, SNU-1, Hep-G2 and NCI-H23 cells with the strongest effect towards SNU-1 cells. This study confirms that coumarins have potent cytotoxic effects as reported previously. However, the level of cytotoxicity might vary due to the presence of different side chains. Therefore, further study on structure-activity relationship on benjaminin derivatives could be performed to improve its cytotoxicity towards cancer cells.

\section{ACKNOWLEDGMENT}

The authors acknowledge financial support from Malaysian Ministry of Education (MOE) under the Fundamental Research Grant Scheme (FRGS/1/2019/ STG01/TAYLOR/02/1).

\section{REFERENCES}

Alkhamaiseh, S.I., Taher, M., Ahmad, F., Qaralleh, H., Althunibat, O.Y., Susanti, D. \& Ichwan, S.J.A. (2012). The phytochemical content and antimicrobial activities of Malaysian Calophyllum canum (stem bark). Pakistan Journal of Pharmaceutical Sciences, 25, 555-563.

Alkhamaiseh, S.I., Taher, M., Ahmad, F., Susanti, D., Jauhari, S. \& Ichwan, A. (2011). Antioxidant and cytotoxic activities of Calophyllum rubiginosum. International Journal of Phytomedicine, 3, 157-163.

Ee, G.C.L., Mah, S.H., Teh, S.S., Rahmani, M., Go, R. \& Taufiq-Yap, Y.H. (2011). Soulamarin, a new coumarin from stem bark of Calophyllum soulattri. Molecules, 16, 9721-9727.

Guilet, D., Seraphin, D., Rondeau, D., Richomme, P. \& Bruneton, J. (2001a). Cytotoxic coumarins from Calophyllum dispar. Phytochemistry, 58, 571-575. 
Guilet, D., Helesbeux, J.J., Seraphin, D., Sevenet, T., Richomme, P. \& Bruneton, J. (2001b). Novel cytotoxic 4-phenylfuranocoumarins from Calophyllum dispar. Journal of Natural Products, 64, 563-568.

Ito, C., Itoigawa, M., Furukawa, H., Tokuda, H., Okuda, Y., Mukainaka, T., Okuda, M. \& Nishino, H. (1999). Anti-tumor-promoting effects of 8-substituted 7-methoxycoumarins on Epstein-Barr virus activation assay. Cancer Letters, 138, 87-92.

Itoigawa, M., Ito, C., Tan, H.T., Kuchide, M., Tokuda, H., Nishino, H. \& Furukawa, H. (2001). Cancer chemopreventive agents, 4-phenylcoumarins from Calophyllum inophyllum. Cancer Letters, 169, 15-19.

Khan, M.R., Kihara, M. \& Omoloso, A.D. (2002). Antimicrobial activity of Calophyllum soulattri. Fitoterapia, 73, 741-743.

Mah, S.H., Ee, G.C.L. \& Teh, S.S. (2013). Chemistry and cytotoxic activity of essential oil from the stem bark of Calophyllum soulattri. Asian Journal of Chemistry, 25, 8831-8832.

McKee, T.C., Fuller, R.W., Covington, C.D., Cardellina, J.H., Gulakowski, R.J., Krepps, B.L., McMahon, J.B. \& Boyd, M.R. (1996). New pyranocoumarins isolated from Calophyllum lanigerum and Calophyllum teysmannii. Journal of Natural Products, 59, 754-758.

Mosmann, T. (1983). Rapid colorimetric assay for cellular growth and survivals: Application to proliferation and cytotoxic assays. Journal of Immunological Methods, $65,55-63$.

Reyes-Chilpa, R., Estrada-Muniz, E., Apan, T.R., Amekraz, B., Aumelas, A., Jankowski, C.K. \& VazquezTorres, M. (2004). Cytotoxic effects of mammea type coumarins from Calophyllum brasiliense. Life Sciences, $75,1635-47$
Sahimi, M.S.M., Ee, G.C.L., Mahaiyiddin, A.G., Daud, S., Teh, S.S., See, I. \& Sukari, M.A. (2015). A new natural product compound Benjaminin from Calophyllum benjaminum. Pertanika Journal of Tropical Agricultural Science, 38, 1-6.

Souza, M.D.O.C., Beserra, A.M., Martins, D.C., Real, V.V., Santos, R.A., Rao, V.S., Silva, R.M. \& Martins, D.T. (2009). In vitro and in vivo anti-Helicobacter pylori activity of Calophyllum brasiliense Camb. Journal of Ethnopharmacology, 123, 452-428.

Spino, C., Dodier, M. \& Sotheeswaran, S. (1998). AntiHIV coumarins from Calophyllum seed oil. Bioorganic \& Medicinal Chemistry Letters, 8, 3475-3478.

Tsai, S.C., Liang, Y.H., Chiang, J.H., Liu, F.C., Lin, W.H., Chang, S.J., Lin, W.Y., Wu, C.H. \& Weng, J.R. (2012). Anti-inflammatory effects of Calophyllum inophyllum L. in RAW264.7 cells. Oncology Reports, 28, 1096-1102.

Verotta, L., Lovaglio, E., Vidari, G., Finzi, P.V., Neri, M.G., Raimondi, A., Parapini, S., Taramelli, D. \& Riva, A. (2004). Bombardelli E. 4-Alkyl- and 4-phenylcoumarins from Mesua ferrea as promising multidrug resistant antibacterials. Phytochemistry, 65, 2867-2879.

Win, N.N., Awale, S., Esumi, H., Tezuka, Y. \& Kadota, S. (2008). Novel anticancer agents, kayeassamins C-I from the flower of Kayea assamica of Myanmar. Bioorganic \& Medicinal Chemistry, 16, 8653-8660. 